\title{
Significance of the Fanconi Anemia FANCD2 Protein in Sporadic and Metastatic Human Breast Cancer
}

Philip S. Rudland, ${ }^{\star \dagger \ddagger}$ Angela M. Platt-Higgins, ${ }^{* \dagger}$ Lowri M. Davies, ${ }^{*}{ }^{\dagger}$ Suzete de Silva Rudland, ${ }^{* \dagger}$ James B. Wilson, ${ }^{\dagger}$ Abdulaziz Aladwani, ${ }^{\dagger}$ John H.R. Winstanley, ${ }^{\S}$ Dong L. Barraclough, ${ }^{\star \dagger \ddagger}$ Roger Barraclough, ${ }^{* \dagger}$ Christopher R. West, ${ }^{4}$ and Nigel J. Jones ${ }^{\dagger}$

From the Cancer and Polio Research Fund Laboratories," Molecular Oncology and Stem Cell Biology Group, ${ }^{\dagger}$ School of Biological Sciences, and the Cancer Tissue Bank Research Centre, ${ }^{\ddagger}$ University of Liverpool, Liverpool; the Department of Surgery, ${ }^{\S}$ Royal Bolton Hospital, Bolton; and the Division of Public Health, "Medical School, University of Liverpool, Liverpool, United Kingdom

FANCD2, a pivotal protein in the Fanconi anemia and BRCA pathway/network, is monoubiquitylated in the nucleus in response to DNA damage. This study examines the subcellular location and relationship with prognostic factors and patient survival of FANCD2 in breast cancer. Antibodies to FANCD2 were used to immunocytochemically stain 16 benign and 20 malignant breast specimens as well as 314 primary breast carcinomas to assess its association with subcellular compartment and prognostic factors using Fisher's Exact test or with patient survival over 20 years using Wilcoxon-Gehan statistics. Immunoreactive FANCD2 was found in the nucleus and cytoplasm of all 16 benign tissues, but nuclear staining was lost from a significant 19/20 malignant carcinomas $(P<0.0001)$. Antibodies to FANCD2 stained the cytoplasm of 196 primary carcinomas, leaving 118 as negatively stained. Negative cytoplasmic staining was significantly associated with positive staining for the metastasis-inducing proteins S100A4, S100P, osteopontin, and AGR2 (P $\leq$ 0.002). Survival of patients with FANCD2-negative carcinomas was significantly worse $(P<0.0001)$ than those with positively stained carcinomas, and only $4 \%$ were alive at the census date. Multivariate regression analysis identified negative staining for cytoplasmic FANCD2 as the most significant indicator of patient death $(P=$ 0.001). Thus FANCD2's cytoplasmic loss in the primary carcinomas may allow the selection of cells overexpressing proteins that can induce metastases be- fore surgery. (Am J Pathol 2010, 176:2935-2947; DOI: 10.2353/ajpath.2010.090779)

Previous reports have shown that the expression of four proteins that can induce metastasis in experimental rats are highly significantly correlated with each other and separately with early patient death in human breast cancer. These four proteins are S100A4, osteopontin (OPN), AGR2, and S100P..$^{1-4}$ If their expression is coordinated, then markers of the underlying mechanism should be even more highly correlated with patient demise. One possible coordination mechanism is the generation of an unstable genome by failure of a DNA repair pathway or some other protective mechanism. The majority of familial breast cancer is associated with individuals heterozygous for the BRCA1 or BRCA2 genes that encode proteins important for the repair of DNA double strand breaks and interstrand crosslinks by homologous recombination.,6 Biallelic inactivation of BRCA2 results in one form of the cancer-prone syndrome Fanconi anemia (complementation group FA-D1) and the BRCA2/FANCD1 protein operates with 12 other Fanconi anemia (FA) proteins and BRCA1 in a multifaceted response to DNA damage known as the FA/ BRCA tumor suppressor pathway/network. ${ }^{7-10}$ Eight of the 13 proteins, together with two FA-associated-proteins, participate in a nuclear core-complex that is required for the monoubiquitylation of FANCD2 and FANCl. ${ }^{8}$ FANCD2 is pivotal in the FA pathway translocating to chromatin and on

Supported by grants from the Cancer and Polio Research Fund and North West Cancer Research Fund (CR751).

Accepted for publication February 18, 2010.

The costs of publication of this article were defrayed, in part, by the payment of page changes. This article must therefore be hereby marked advertisement in accordance with 18 U.S.C. Section 1734 solely to indicate that fact.

Supplemental material for this article can be found on http://ajp. amjpathol.org.

Current address of D.L.B.: School of Clinical Sciences, $4^{\text {th }}$ Floor Duncan Building, University of Liverpool, Liverpool, L69 3GA, United Kingdom.

Address reprint requests to Prof. Philip S. Rudland or Dr. Nigel J. Jones, School of Biological Sciences, Biosciences Building, Crown Street, University of Liverpool, Liverpool, L69 3BX, United Kingdom. E-mail: dell@liv.ac.uk and nijones@liv.ac.uk. 
monoubiquitylation, co-localizing with BRCA1, BRCA2 and the recombinase RAD51 in DNA damage inducible foci. ${ }^{11-15}$ FANCD2 is primarily regarded as being active within the nucleus and specifically in chromatin, although a cytoplasmic function has recently been proposed. ${ }^{16}$ The FA proteins BRCA2/FANCD1 and FANCN/PALB2 are believed to function downstream of, or in parallel with, FANCD2 monoubiquitylation and FANCN and FANCJ/ $B R I P 1$, like BRCA2, are now considered to be breast cancer susceptibility genes. ${ }^{17,18}$ While FANCD2 directly interacts with BRCA2 ${ }^{19}$ and is found in complex with BRCA2 in mammalian cells, ${ }^{13,20}$ there is no direct evidence for changes in FANCD2 in the development of familial breast cancer. However, FancD2 knockout mice exhibit an increased incidence of epithelial cancers including hepatic, ovarian, and mammary tumors, ${ }^{21}$ reduced FANCD2 expression is associated with familial ovarian cancer ${ }^{22}$ and several FA core-complex genes have now been implicated with several types of sporadic cancer, including ovarian and pancreatic cancer. ${ }^{23}$ This suggests that a failure to express or post-translationally modify FANCD2 may play a role in the development of sporadic breast cancer. In contrast, a previous report in human breast cancer over a relatively short 6-year follow-up has suggested that high nuclear FANCD2 expression is correlated with poor patient survival. ${ }^{24}$ To resolve this apparent contradiction we now show that breast carcinomas contain mainly cytoplasmic FANCD2 and that its loss is strongly correlated with the expression of the four metastasis-inducing proteins and particularly with premature death of patients with sporadic breast cancer over a much longer follow-up period of 20 years.

\section{Materials and Methods}

\section{Patients and Specimens}

Initially, samples were taken from 36 patients, who presented at general surgery clinics in the Merseyside Region of the North West of England between 1976 and 1982, 16 with benign breast lesions (9 fibroadenomas, 7 benign breast disease) and 20 with primary malignant breast cancer (all invasive ductal carcinomas). ${ }^{25}$ Secondly, samples of 314 primary tumors were collected between the same dates from unselected operable (Stage I and II) breast cancer patients treated by simple mastectomy with sampling of axillary lymph nodes (17\%) or modified radical mastectomy (83\%); no adjuvant therapy was given., ${ }^{2,26}$ Patient age ranged from 30 to 81 years (average 60 years) and $98.5 \%$ had invasive carcinoma (92.4\% invasive ductal and $6.0 \%$ invasive lobular) with only $1.5 \%$ of special type (colloid and medullary). The mean period of follow-up of patients was 16 years, ranging from 14 to 20 years. The distribution of tumor types, tumor sites, node status, menopausal status, histological grade, and ethics approval was obtained as described previously2,3 (Supplemental Table S1, at http://ajp.amjpathol.org). Overall patient survival and the significant pathological prognostic variables over 20 years have been summarized recently. ${ }^{1}$

\section{Cell Lines and Cell Culture}

Normal human breast epithelial cell lines SVE3, Huma 7 and benign human mammary epithelial cell lines Huma 121, Huma 123 were described previously. ${ }^{1,27,28}$ These and the malignant epithelial cell lines derived from pleural effusions of breast cancer patients MCF-7, T47D, MDA-MB157, and MDA-MB-231 were cultured as described ${ }^{27}$; the MCF-7 and T47D were relatively noninvasive (low invasive), and MDA-MB-157 and MDA-MB-231 were highly invasive (high invasive). ${ }^{29}$ MDA-MB-157-FANCD2 was generated by transducing MDA-MB-157 cells with a retroviral supernatant of a wild-type FANCD2 cDNA pMMP construct ${ }^{30}$ and subsequent selection in puromycin as previously described. ${ }^{31}$ Fibroblast cell lines PD20 and PD733, isolated from unrelated hypomorphic FANCD2-deficient patients and PD203-15 (chromosome 3p-complemented PD20), ${ }^{32}$ were grown as previously described. ${ }^{20}$ Mitomycin C (MMC; Sigma, UK) exposure (50 nmol/L), when used, was for 18 hours.

\section{Growth Inhibition and Chromosomal Aberration Analysis}

Growth inhibition by MMC was determined in three independent experiments as previously described. ${ }^{33}$ Chromosomal aberrations were assayed essentially as described, ${ }^{34}$ except 1 to $3 \times 10^{5}$ cells were seeded per microscope slide, and incubated for 48 hours before the addition of MMC for a further 24 hours. Colcemid was added and mitotic cells were allowed to accumulate for 2 hours before fixation and staining. Metaphase spreads were scored for chromosomal aberrations using the classification described by Scott et al. ${ }^{35}$

\section{Immunocytochemistry}

Histological sections $(\sim 4 \mu \mathrm{m})$ cut from paraffin blocks were dewaxed and rehydrated, and endogenous peroxidase activity inhibited. ${ }^{36}$ Sections were incubated at room temperature for 30 minutes with $2 \%(\mathrm{w} / \mathrm{v})$ bovine serum albumin in PBS and then at room temperature for 3 hours with rabbit polyclonal anti-FANCD2 primary antibody (H300; sc-28194, Santa Cruz CA, ) diluted 1:100 in 2\% $(w / v)$ bovine serum albumin in PBS. FANCD2 antibodies recognize both the non-monoubiquitylated and monoubiquitylated isoforms of FANCD2. ${ }^{20}$ The bound antibody was detected using the DAKO EnVision+ System-HRP (DAKO Ltd, Ely, UK). ${ }^{37}$ Sections were counterstained blue with Mayer's hemalum and mounted in DPX (Merck, Poole, UK). Another rabbit antibody (LS-B493, Life SciencesBioscience, Nottingham, UK) was used at a dilution of 1:200 in the first 39 specimens selected at random to confirm results. Blocked antibody was prepared by mixing rabbit anti-FANCD2 with $180 \mu \mathrm{g} / \mathrm{ml}$ immunizing peptide mapping near the C-terminus of human FANCD2 (sc-23584P, Santa Cruz). Cell lines were preserved in $10 \%(\mathrm{v} / \mathrm{v})$ neutral buffered formalin for 2 hours, replaced with $70 \%(\mathrm{v} / \mathrm{v})$ ethanol for 1 hour and the cell pellet was embedded in $3 \%(\mathrm{w} / \mathrm{v})$ molten agar, and embedded in 
paraffin wax, before being sectioned as for tumor specimens. Photographs were recorded as described previously. ${ }^{2}$

Specimens were analyzed and scored using light microscopy by two independent observers, including one qualified pathologist, according to the percentage of tumor/mammary cells showing positive immunocytochemical staining for nuclear and/or cytoplasmic FANCD2. The percentage of stained tumor/mammary cells was recorded from two well-separated sections of each specimen, 10 fields per section at $\times 200$ magnification, at a minimum of 200 cells per field. ${ }^{2}$ Staining for FANCD2 was evaluated in five classes: negative $(-),<1 \%$; borderline $( \pm), 1 \%$ to $5 \%$; intermediate $(+), 5 \%$ to $25 \%$; moderate $(++), 25$ to $50 \%$; and strong $(+++),>50 \%$ of the nucleicytoplasms stained, as described previously. ${ }^{4}$ In the first experiment, both the malignant and benign tumor/mammary cells were scored for nuclear and cytoplasmic staining, in the second experiment only the carcinoma cells were assessed for cytoplasmic staining and any positively staining host or nonmalignant breast cells were ignored. Immunocytochemical staining data on the same set of patients had been obtained previously for S100A $4,{ }^{2} \mathrm{OPN},{ }^{3} \mathrm{C}$ erbB-2, c-erbB-3, estrogen receptor $\alpha$, progesterone receptor, pS2, p53, ${ }^{38}$ and ${\mathrm{S} 100 \mathrm{P}^{4}}^{4}$ using a $5 \%$ cut-off and for cathepsin $D^{26}$ and anterior gradient 2 (AGR2) ${ }^{1}$ using a $1 \%$ cut-off to differentiate between the negatively and positively staining carcinomas (Supplemental Table S1, at http://ajp. amjpathol.org). That for nuclear Ki-67 was obtained by incubation for 1 hour with monoclonal MIB-1 anti-Ki-67 (M7240; Dako Ltd., Ely, UK) diluted 1:100 on sections pretreated by microwaving for 25 minutes in $10 \mathrm{mmol} / \mathrm{L}$ TrisEDTA at pH 9.0 and bound antibody was detected by the Dako Envision+System-HRP as described for FANCD2, analysis was made using a 1\% cut-off (Supplemental Table $\mathrm{S} 1$, at $h$ ttp://ajp.amjpathol.org). Assessment of the cell lines in histological sections was the mean of eight fields for nuclear and cytoplasmic staining.

Immunofluorescent staining of MCF-7 and T47D cell lines was conducted with rabbit (H300; Sc-28194, Santa Cruz) and goat (E19; sc-23584, Santa Cruz) polyclonal anti-FANCD2 at dilutions of 1:10 on neutral buffered formalin or methanol-fixed cultures grown in multiwell LabTek 8 chambered slides (177445, Nunc Scientific, Roskilde, Denmark) and bound antibodies were detected with the relevant fluorescein isothiocyanate-labeled second antibodies at 1:50 dilution, as described previously. ${ }^{39}$

\section{Statistical Methods}

The association of immunocytochemical staining for FANCD2 with malignancy in breast specimens from benign lesions/tumors and primary carcinomas and of cytoplasmic staining for FANCD2 with other tumor variables was assessed using Fisher's Exact test, two sided values of probability $(P)$ are given. ${ }^{40}$ The cut-off values between negative or positive staining for FANCD2 and for the other proteins was set at $1 \%$ or $5 \%$, as above. For multiple comparisons the Holm-Bonferroni adjustment, 1-(1-P) was made to the resultant $P$ values; $n=$ no. tumor vari- ables. ${ }^{40}$ The significance of the difference in means of the \% stained nuclei and cytoplasms of the different cell lines was calculated using Student's t-test. Association of cytoplasmic staining for FANCD2 in primary breast carcinomas with patient survival was calculated from life tables ${ }^{40}$ constructed from survival data using KaplanMeier plots and analyzed by generalized Wilcoxon (Gehan) statistics. Patients who died of causes other than cancer were censored. ${ }^{41}$ Unadjusted relative risk (RR) for survival with $95 \%$ confidence interval $(95 \% \mathrm{Cl})$ was calculated using Cox's univariate analysis. ${ }^{40}$ To determine whether the association of patient survival with FANCD2 was independent of other tumor variables found to be significantly associated in univariate analyses, a multivariate analysis was performed using Cox's proportional hazards model on 159 patients with full data sets. ${ }^{42}$ This analysis treated variables as categorical in positive and negative groups defined above and operationally used the forward stepwise Wald method which generated the most significant variable at each step (Supplemental Table S2, at $h$ ttp://ajp.amjpathol.org).

\section{Immunoblotting for FANCD2}

This was performed as described ${ }^{20,43}$ using the same H300 antibody as for the immunocytochemical studies. Whole cell extracts were prepared as previously, ${ }^{20}$ while nuclear and cytoplasmic fractions were prepared from 1 to $2 \times 10^{7}$ exponentially growing MMC-treated cells (18 hours) with Sigma's Celllytic-NuCLEAR extraction kit (Sigma, UK). Fractionation was monitored by immunoblotting with antibodies to TATA binding protein and tubulin (ab818, ab56676; Abcam, Cambridge, UK).

\section{Results \\ Comparison of Immunocytochemical Staining of Benign and Malignant Lesions for FANCD2}

The benign lesions, both fibroadenomas (Figure 1A) and benign breast disease (not shown) showed strong staining of the tumor/mammary cells for FANCD2 with moderate cytoplasmic and strong nuclear staining, particularly of the myoepithelial cells (Figure 1B). In contrast, invasive carcinomas ranged from those showing strong cytoplasmic staining (Figure 1, C and D) to those showing no cytoplasmic staining (Figure 1E). A group of invasive carcinomas showed borderline cytoplasmic staining ( 1 to $5 \%$ of the carcinoma cells positively stained) for FANCD2 (Figure 1F). There was little nuclear staining of any of the carcinomas (Figure 1, C and D). When serial sections of positive invasive carcinomas were incubated with blocked anti-FANCD2, all cytoplasmic and nuclear staining was abolished (Figure 1, $\mathrm{G}$ and $\mathrm{H}$ ). The same results of specific cytoplasmic staining of a malignant carcinoma were obtained at low, medium and high power using the same antibody (Supplemental Figures S1 and S2, at http://ajp.amjpathol.org) or a different antibody for FANCD2 (Supplemental Figure S3, at http://ajp.amjpathol.org). In the 36 initial samples of breast lesions; staining for 

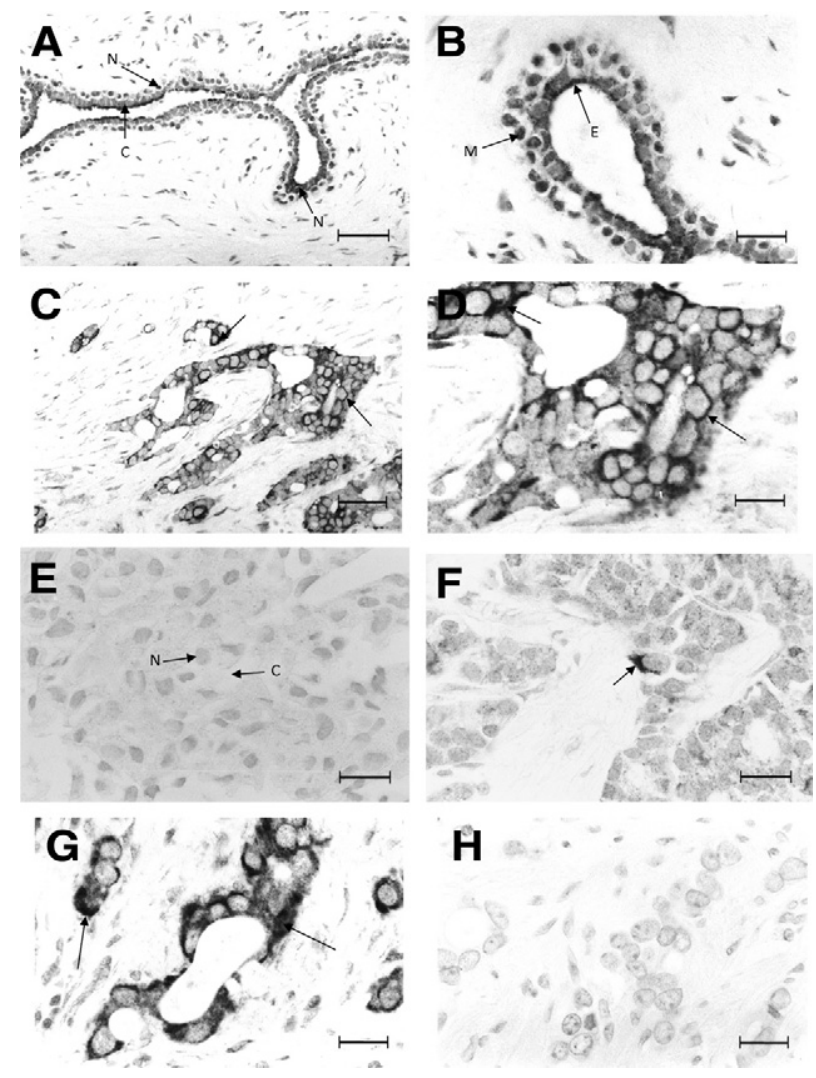

Figure 1. Immunocytochemical staining for FANCD2. A: Fibroadenoma showing strong $(+++)$ nuclear staining $(\mathrm{N})$ and moderate $(++)$ cytoplasmic staining $(\mathrm{C})$ of the tumor cells. B: Fibroadenoma at higher magnification showing stronger nuclear staining of the myoepithelial cells $(\mathrm{M})$ than the surrounding epithelial cells (E) of the tumor. C and D: Invasive carcinoma showing strong $(+++)$ cytoplasmic staining (arrows) of the carcinoma cells at lower $(\mathbf{C})$ and higher (D) magnification. E: invasive carcinoma showing no nuclear (N) or cytoplasmic staining (C) of the carcinoma cells. F: invasive carcinoma showing borderline (1-5\%) cytoplasmic staining (arrow) of the carcinoma cells. $\mathbf{G}$ and $\mathbf{H}$ : Serial sections of invasive carcinoma incubated with (G) anti-FANCD2 and (H) anti-FANCD2 pre-incubated with immunizing peptide showing $(\mathbf{G})$ strong $(+++)$ cytoplasmic staining (arrows) and $(\mathbf{H})$ no staining (-), respectively. Magnification: $\times 220 \mathbf{A}$ and $\mathbf{C} ; \times 550 \mathbf{B}$ and D-H. Scale bar: $50 \mu \mathrm{m}$ (A and $\mathbf{C}) ; 20 \mu \mathrm{m}(\mathbf{B}$ and $\mathbf{D}-\mathbf{H})$.

FANCD2 was separated into two categorical groups, a negative and a positive staining group, the cut-off being $1 \%$ of the mammary/tumor cells stained for FANCD2 (Table 1). The pure lesions exhibited a highly significant association between the presence of nuclear staining in the benign rather than in the malignant lesions using a $1 \%$ cut-off (Fisher's Exact test, $P<0.0001$ ), as did the pure and benign-within-malignant lesions together $(P<$ $0.0001)$. There was also a significant association at the $1 \%$ cut-off between positive cytoplasmic staining and benign lesions, either when analyzing only the pure lesions $(P=0.011)$, or when including the benign-withinmalignant lesions $(P=0.001)$ (Table 1$)$. Similarly when the categorical groups were separated using a 5\% cutoff, there was a highly significant association between positive staining of the nucleus $(P<0.0001)$ or cytoplasm ( $P \leq 0.004)$ for FANCD2 and benign rather than malignant lesions, when analyzing either the pure lesions or including the benign-within-malignant lesions (not shown).

\section{Immunochemical Staining and Blotting of Cell Lines for FANCD2}

Sections containing epithelial cell lines were immunocytochemically stained for FANCD2. There was no significant difference in the \% stained nuclei (Student's $t$-test, $P \geq 0.17)$ and little in cytoplasms $(P \geq 0.07)$ for cell lines isolated from normal/benign breasts, but nuclear staining for FANCD2 of the malignant cell lines (MCF-7, T47D, MDA-MB-157, MDA-MB-231) was significantly reduced by threefold or more compared with the cell lines isolated from normal/benign tissue (SVE3, Huma 7, Huma 121, Huma 123) $(P<0.0001)$. The low invasive malignant cell lines (MCF-7, T47D) retained a similar 51 to 53\% cytoplasmic staining observed with normal/benign cell lines (43 to 53\%), whereas the high invasive cell lines (MDAMB-157, MDA-MB-231) possessed virtually no cytoplasmic $(P<0.0001)$, and no nuclear staining for FANCD2 $(P \leq 0.0002)$ (Table 2 ). The results of cytoplasmic staining of FANCD2 for MCF-7 and T47D were confirmed by direct immunofluorescent staining of cultured cells using the original rabbit antibody (Supplemental Figure S4, at http://ajp.amjpathol.org) and a different goat antibody to FANCD2 (Supplemental Figure S5, at http://ajp.amjpathol. org). When fractionated, the immortalized normal cell line SVE3 and the benign cell line Huma 121 yielded two nuclear protein bands of $155 \mathrm{kDa}$ (FANCD2-S) and 162 kDa (FANCD2-L) and one cytoplasmic band of $155 \mathrm{kDa}$ (FANCD2-S). Only one cytoplasmic band of $155 \mathrm{kDa}$ (FANCD2-S) was detected in the low invasive malignant cell line MCF-7 (Figure 2A) and no bands at all were observed in the high invasive malignant cell lines (MDAMB-157, MDA-MB-231) (Figures 2A and 3A) with or without MMC.

Sections of the similarly prepared human fibroblast cell line deficient in FANCD2, PD20, showed virtually no nuclear or cytoplasmic staining with anti-FANCD2, with or without MMC. Contrastingly, when PD20 was functionally complemented by microcell-mediated transfer of chromosome 3p yielding PD20-3-15, ${ }^{32}$ there was a significant increase in \% nuclear and cytoplasmic staining by 5.5fold $(P=0.0003)$ and 32-fold $(P<0.0001)$, respectively, in corresponding histological sections (Table 2). After PD20-3-15 was treated with $50 \mathrm{nmol} / \mathrm{L} \mathrm{MMC,} \mathrm{nuclear}$ staining further increased (6.5-fold), while cytoplasmic staining decreased by twofold (both $P<0.0001$ ). PD733, isolated from another patient, ${ }^{32}$ also showed little nuclear or cytoplasmic staining. Immunoblotting of whole cell extracts of PD20-3-15 showed two protein bands (data not shown) corresponding to the non-ubiquitylated (FANCD2-S) and mono-ubiquitylated (FANCD2-L) isoforms. ${ }^{11,20,32}$ When fractionated, PD20-3-15 yielded two nuclear protein bands of 155 kDa (FANCD2-S) and 162 $\mathrm{kDa}$ (FANCD2-L), and one cytoplasmic band of $155 \mathrm{kDa}$ (FANCD2-S), whereas both were undetectable in PD20 (Figure 2B). FANCD2 was not detectable in PD733 by Western blotting (data not shown), as previously reported by others. ${ }^{32}$ 
Table 1. Nuclear and Cytoplasmic Staining for FANCD2 in Both Benign and Malignant Lesions

\begin{tabular}{|c|c|c|c|c|c|c|}
\hline \multirow[b]{2}{*}{ Pathological lesions } & \multicolumn{3}{|c|}{ Pure lesions* } & \multicolumn{3}{|c|}{ All lesions ${ }^{\dagger}$} \\
\hline & \multicolumn{2}{|c|}{$\begin{array}{l}\text { Nuclear staining } \\
\text { number }(\%)\end{array}$} & $\begin{array}{c}\text { Statistical } \\
\text { significance }^{\S}\end{array}$ & \multicolumn{2}{|c|}{$\begin{array}{l}\text { Nuclear staining }{ }^{\ddagger} \\
\text { number }(\%)\end{array}$} & $\begin{array}{c}\text { Statistical } \\
\text { significance }^{\S}\end{array}$ \\
\hline \multirow[t]{2}{*}{$\begin{array}{l}\text { Benign } \\
\text { Malignant }\end{array}$} & $\begin{array}{c}- \\
0(0) \\
19(95)\end{array}$ & $\begin{array}{c}+ \\
16(100) \\
1(5)\end{array}$ & $<0.0001$ & $\begin{array}{c}- \\
0(0) \\
19(95)\end{array}$ & $\begin{array}{c}+ \\
31(100) \\
1(5)\end{array}$ & $<0.0001$ \\
\hline & \multicolumn{2}{|c|}{$\begin{array}{c}\text { Cytoplasmic staining } \\
\text { number }(\%)\end{array}$} & $\begin{array}{c}\text { Statistical } \\
\text { significance }\end{array}$ & \multicolumn{2}{|c|}{$\begin{array}{c}\text { Cytoplasmic staining }{ }^{\ddagger} \\
\text { number }(\%)\end{array}$} & $\begin{array}{c}\text { Statistical } \\
\text { significance }\end{array}$ \\
\hline $\begin{array}{l}\text { Benign } \\
\text { Malignant }\end{array}$ & $\begin{array}{l}\quad- \\
0(0) \\
7(35)\end{array}$ & $\begin{array}{c}\quad+ \\
16(100) \\
13(65)\end{array}$ & 0.011 & $\begin{array}{l}- \\
0(0) \\
7(35)\end{array}$ & $\begin{array}{l}\quad+ \\
31(100) \\
13(65)\end{array}$ & $0.0001^{9}$ \\
\hline
\end{tabular}

*Pure lesions consist of 9 fibroadenomas and 7 benign breast disease for benign lesions and 20 invasive ductal carcinomas for malignant lesions.

${ }^{+}$All lesions include benign lesions in both 16 pure benign lesions and benign breast disease in 15 malignant carcinomas, as well as the 20 invasive ductal carcinomas.

${ }^{\ddagger}$ Numbers staining within the nucleus or cytoplasm using a 1\% cut-off of mammary/carcinoma cells stained; values in brackets are percentages (\%) stained for either type of lesion.

§Probability $(P)$ was determined using Fisher's exact test (2-sided)

'Yates' correction used as expected frequency was less than 5 . Without this, $P=0.002$.

\section{FA-Like Functional Phenotype in High Invasive Malignant Breast Cancer Cell Lines}

Given that MDA-MB-157 and MDA-MB-231 exhibit virtually no immunocytochemically detectable or immunofluorescent staining for FANCD2, it might be anticipated that these cell lines would possess a Fanconi anemia-like phenotype. In a growth inhibition assay both MDA-MB157 and MDA-MB-231 displayed a hypersensitivity to MMC that was similar to the Fanconi anemia patientderived FA-D2 cell line PD20 (Figure 3B). MDA-MB-157 also scored positively in a MMC chromosomal breakage test that is used in the diagnosis of FA patients (Figure 3C). ${ }^{44}$ MDA-MB-157 cells treated with $100 \mathrm{nmol} / \mathrm{L} \mathrm{MMC}$ showed a high level of chromosomal aberrations, with the exchanges all being of the type (complex chromatid exchange figures) typically seen in FA patient cells. ${ }^{44}$ The introduction of a wild-type cDNA for FANCD2 into MDAMB-157 restored expression of FANCD2 protein (Figure $3 \mathrm{~A}$ ) and complemented both the cellular and chromosomal sensitivity of the cell line to MMC almost completely (Figure 3, B and C).

Table 2. Nuclear and Cytoplasmic Staining of Human Cell Lines for FANCD2

\begin{tabular}{|c|c|c|c|}
\hline \multirow[b]{2}{*}{ Breast cell line* } & \multirow[b]{2}{*}{ Classification* } & \multicolumn{2}{|c|}{ Percentage stained $^{\dagger}$} \\
\hline & & Nucleus & Cytoplasm \\
\hline SVE3 & Immortalized normal & $23 \pm 5$ & $53 \pm 12$ \\
\hline Huma 7 & Immortalized normal & $23 \pm 4$ & $52 \pm 13$ \\
\hline Huma 121 & Immortalized benign & $24 \pm 5$ & $43 \pm 8$ \\
\hline Huma 123 & Immortalized benign & $21 \pm 3$ & $53 \pm 4$ \\
\hline MCF-7 & Malignant: low invasive & $8 \pm 3^{\S}$ & $53 \pm 8$ \\
\hline T47D & Malignant: low invasive & $5 \pm 2^{\S}$ & $51 \pm 6$ \\
\hline MDA-MB-157 & Malignant: high invasive & $0 \pm 0^{\S}$ & $1 \pm 1^{\S}$ \\
\hline MDA-MB-231 & Malignant: high invasive & $0 \pm 0^{\S}$ & $1 \pm 1^{\S}$ \\
\hline \multirow{2}{*}{$\begin{array}{c}\text { FANCD2-deficient } \\
\text { cell line }\end{array}$} & & \multicolumn{2}{|c|}{ Percentage stained $^{\dagger}$} \\
\hline & Mitomycin $\mathrm{C}^{\ddagger}$ & Nucleus & Cytoplasm \\
\hline \multirow[t]{2}{*}{ PD20 } & - & $2 \pm 1$ & $2 \pm 1$ \\
\hline & + & $2 \pm 1$ & $2 \pm 1$ \\
\hline PD733 & - & $2 \pm 1$ & $3 \pm 1$ \\
\hline \multirow{2}{*}{ PD20-3-15 } & - & $11 \pm 4^{\pi}$ & $63 \pm 1^{1}$ \\
\hline & + & $71 \pm 11^{\Uparrow}$ & $32 \pm 8^{\pi}$ \\
\hline
\end{tabular}

*Epithelial cell lines were derived from normal (SVE3, Huma 7), benign (Huma 121, Huma 123), malignant low invasive (MCF-7, T47D), or malignant high invasive (MDA-MB-157, 231) breast sources (Materials and Methods).

†Immunocytochemical staining for FANCD2 showing the mean percentage \pm standard deviation $(n=8)$ of positive nuclei and cytoplasms.

₹ PD20 (FANCD2-deficient) or PD20-3-15 (PD20 functionally complemented by microcell mediated transfer of chromosome 3p) fibroblasts were grown in the presence $(+)$ or absence $(-)$ of $50 \mathrm{nmol} / \mathrm{L}$ mitomycin C for 18 hours. A second unrelated FANCD2-deficient fibroblast cell line PD733 was grown without MMC.

\$Significantly different in Student's t-test for nuclear staining for SVE3, Huma 7, Huma 121, Huma 123, compared to MCF-7, T47D, MDA-MB-157, MDA-MB-231 ( $P<0.0001)$ and in cytoplasmic staining for SVE3, Huma 7, Huma 121, Huma 123, MCF-7, ZR-75 compared to MDA-MB-157, MDA-MB$231(P<0.0001)$ and for MCF-7, T47D versus MDA-MB-157, MDA-MB-231 for nuclear and cytoplasmic staining $(P \leq 0.0002)$.

"Significantly different in Student's $t$-test for PD20 vs PD20-3-15 ( $P \leq 0.0003)$ and for PD20-3-15 with $(+)$ MMC versus without $(-)$ MMC for nuclear and cytoplasmic staining $(P<0.0001)$ but not for PD20 vector alone with $(+) 50 \mathrm{nmol} / \mathrm{L}$ MMC versus without $(-)$ MMC for nuclear and cytoplasmic staining $(P=1)$ 
A

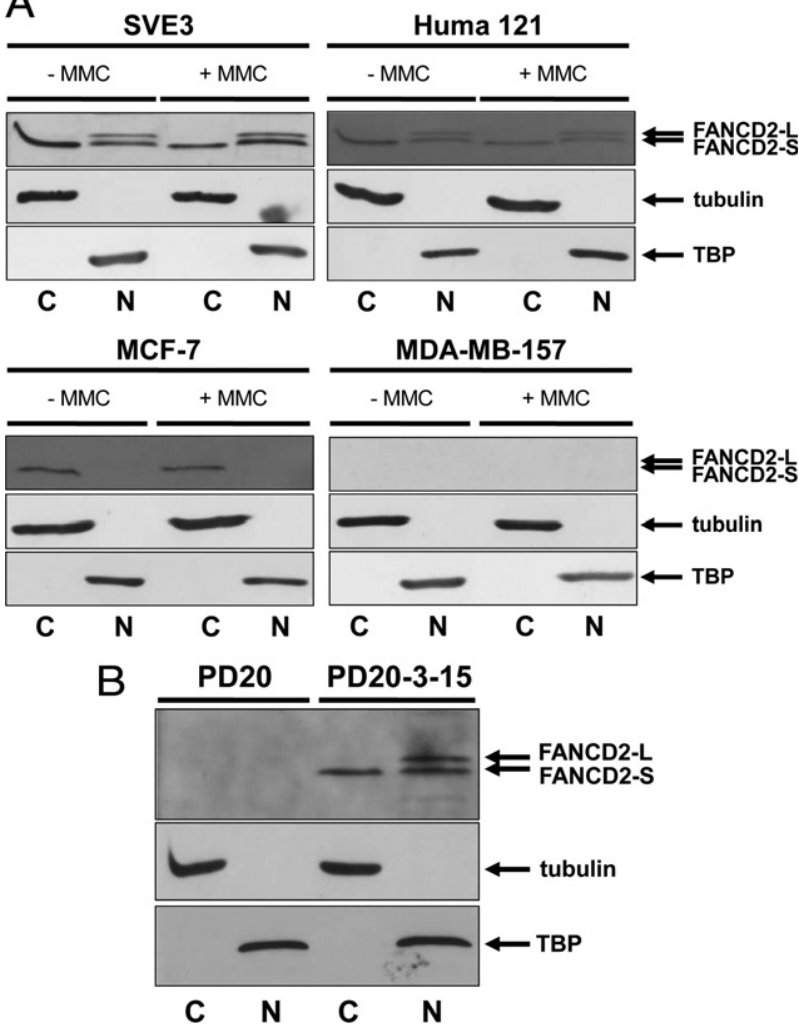

Figure 2. Immunoblotting for FANCD2 in nuclear and cytoplasmic fractions of cultured cell lines. A: Lysates of breast cell lines SVE3, Huma 121, MCF-7, and MDA-MB-157 were fractionated into nuclear and cytoplasmic extracts and Western blotted for FANCD2 (using H300 anti-rabbit antibody). MMC treatment $(+\mathrm{MMC})$ was at $50 \mathrm{nmol} / \mathrm{L}$ for 18 hours before the preparation of lysates. Nuclear $(\mathrm{N})$ extracts show the presence of TATA binding protein (TBP) while cytoplasmic (C) extracts show the presence of tubulin, with no detectable cross-contamination. Immortalized normal (SVE3) and immortalized benign (Huma 121) cell lines both express immunodetectable FANCD2-S (non-monoubiquitylated; $155 \mathrm{kDa}$ ) and FANCD2-L (monoubiquitylated; $162 \mathrm{kDa}$ ) in the nucleus (irrespective of MMC-treatment), while only FANCD2-S is detectable in the cytoplasm. In the low invasive malignant cell line MCF-7, only the non-ubiquitylated FANCD2 (155 kDa) is immunodetectable and this is confined to the cytoplasm of these cells. The high invasive malignant cell line MDA-MB-157 exhibits no immunodetectable FANCD2 in either fraction. The arrows indicate the position of the marker proteins for FANCD2-L, FANCD2-S, tubulin, and TBP. B: PD20 cells (FA-D2 complementation group) and PD20-3-15 cells (PD20 functionally complemented with human chromosome $3 \mathrm{p}$ ) were treated with $50 \mathrm{nmol} / \mathrm{L} \mathrm{MMC} \mathrm{for} 18$ hours before the preparation of lysates. PD20 exhibits no immunodetectable FANCD2 protein. In PD20-3-15, both FANCD2-S (non-monoubiquitylated; $155 \mathrm{kDa}$ ) and FANCD2-L (monoubiquitylated; $162 \mathrm{kDa}$ ) are present in the nucleus, while only FANCD2-S is detectable in the cytoplasm.

\section{Immunochemical Staining of Breast Carcinomas for FANCD2}

Since there was little observable nuclear staining, only the cytoplasmic staining of the malignant carcinoma cells was analyzed in the 314 primary breast carcinomas examined subsequently. On examination, 118 (37.6\%) were classified as not staining ( $-;<1 \%$ cells stained); 99 $(31.5 \%)$ showed borderline staining $(+/-; 1$ to $5 \%$ cells stained) and 97 (30.9\%) showed varying degrees of positive staining $(+,++,+++;>5 \%$ cells stained) for cytoplasmic FANCD2. These were further subdivided into classes of $56(17.8 \%)$ moderate $(+; 5$ to $25 \%$ cells stained), $36(11.5 \%)$ strong ( $++; 25$ to $50 \%$ cells stained), and $5(1.6 \%)$ very strong $(+++;>50 \%$ carci-
B
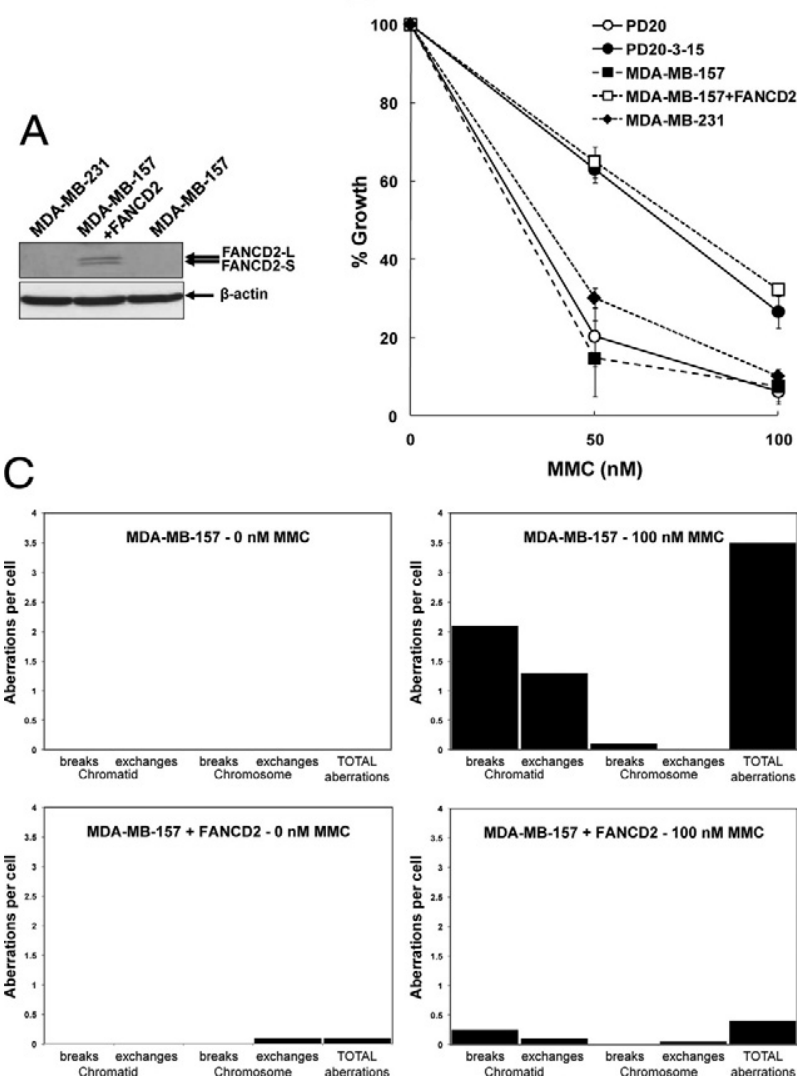

Figure 3. Fanconi anemia-like phenotype in malignant breast cancer cel lines that lack FANCD2 expression. A: Western blots of high invasive malignant cell lines MDA-MB-157 and MDA-MB-231. They lack immunodetectable FANCD2 in whole cell extracts (cells treated with $50 \mathrm{nmol} / \mathrm{L} \mathrm{MMC} \mathrm{for} 18$ hours before preparation of lysates). Transduction of a human cDNA for FANCD2 into MDA-MB-157 restores the expression of both isoforms of FANCD2. Loading has been normalized to that of $\beta$-actin and the arrows indicate the position of the marker proteins for FANCD2-L, FANCD2-S, and $\beta$-actin. B: Growth inhibition by MMC is shown as the mean of three independent experiments for each of the indicated cell lines. The mean percentages $( \pm S D)$ of cells after exposure to MMC for 72 hours, relative to the untreated cells are shown. MDA-MB-157 and MB-MB-231 exhibit a response to MMC that is similar to that shown by the Fanconi anemia patient FA-D2 cell line PD20. The MMC-response of MDA-MB-157 cells transduced with an expression vector for FANCD2 $(+F A N C D 2)$, is very similar to PD203-15, indicating functional complementation of MDA-MB-157 by the wildtype FANCD 2 CDNA. C: Induction of chromosomal aberrations in MDA-MB157 and MDA-MB-157+FANCD2 by MMC. Chromosomal aberrations were scored by metaphase analysis in cells exposed to MMC for 24 hours before the addition of colcemid for 2 hours. For each cell line/treatment, 20 metaphases were scored for chromosomal aberrations using the criteria described by Scott et al. ${ }^{35}$ Chromatid breaks or exchanges involve single arms of metaphase chromosomes, while chromosome breaks or exchanges involve both arms. No chromosomal aberrations were observed in untreated MDA-MB-157 cells while 2 chromosome exchanges (a ring chromosome and a dicentric) were observed in untreated MDA-MB-157+FANCD2 cells. On treatment with MMC, the level of aberrations in MDA-MB-157 increased to a mean of 3.5 chromosomal aberrations per cell. On average, 2.1 chromatid breaks, 1.3 chromatid exchanges and 0.1 chromosome breaks per cell were observed, with all of the chromatid exchanges being complex arrangements (exchanges involving more than two chromosomes), typical of those seen in FA patient cells following MMC treatment. ${ }^{44}$ In contrast, MDA-MB $157+$ FANCD 2 cells exhibited a much more modest increase in chromosomal aberrations with MMC ( 0.4 per cell; 5 chromatid breaks, 2 chromatid exchanges and a single chromosome exchange in the 20 metaphases scored).

noma cells stained) staining carcinomas. Immunoblotting for FANCD2 in carcinoma cell extracts produced bands of varying intensities at approximately $155 \mathrm{kDa}$ consistent with the size of non-monoubiquitylated FANCD2 in ex- 
tracts from PD20-3-15 cells (Figure 2B). In four randomly selected carcinomas, the level of FANCD2 was significantly correlated with the percentage of cytoplasmically stained carcinoma cells (linear regression analysis: $r^{2}=$ $0.998, P=0.0009$ ) (not shown). Hence the percentage of stained carcinoma cells reflects the level of immunoreactive FANCD2 in the specimen. In subsequent analyses, the borderline and positive staining carcinomas were combined into one positively stained group, leaving another categorical group of clearly negatively staining carcinomas. There was good agreement in scoring between the two observers (92.7\% of cases, kappa score, 0.85$)$. Intratumor heterogeneity was similar at $6.1 \%$ for two well separated sections of the same carcinomas. Very similar results for positive cytoplasmic staining of a subset of 39 primary carcinomas was obtained with a second independently isolated antibody to FANCD2 (Supplemental Figure S3, at http://ajp.amjpathol.org) with a level of agreement (94.9\% of cases, kappa score, 0.88 ) similar to that between the two observers with no significant different between these two groups (McNemar Exact test, $P=$ 0.50; using Yates correction $P=0.48)^{40}$ (Supplemental Table S2, at $h$ ttp://ajp.amjpathol.org).

\section{Association of FANCD2 with Other Tumor Variables}

The results of the immunocytochemical staining for cytoplasmic FANCD2 using a 1\% cut-off were cross-tabulated against pathological markers and immunocytochemical staining for molecular variables taken from the same carcinoma samples. These other variables have been reported to have an effect on survival times in nearly $(>70 \%)$ the same set of patients. ${ }^{1-4,38}$ For multiple comparisons of the pathological variables, only low histological grade showed any significant association with cytoplasmic staining for FANCD2 (adjusted Fisher's Exact test, $P=0.015$ ). There was also a significant association between lack of staining for FANCD2 and positive staining for osteopontin $(P<0.0001)$, S100A4 $(P<0.0001)$, S100P $(P=0.002)$, and AGR2 $(P<0.0001)$. All other molecular variables showed no significant association with staining for FANCD2 at the 1\% cut-off level including that for nuclear Ki-67 (Table 3). When the cut-off level for cytoplasmic staining for FANCD2 was set at $5 \%$ of the carcinoma cells stained, there was also a significant association between negative staining for FANCD2 and the same tumor variables $(P \leq 0.02)$ (not shown).

\section{Association of FANCD2 with Patient Survival}

The association of cytoplasmic staining for FANCD2 and cumulative proportion of patients surviving at 12-month intervals after the time of presentation is shown in Figure 4. When the patients were analyzed in their individual staining classes for FANCD2, the five curves showed an almost progressive increase in survival, and were highly significantly different (Wilcoxon test $P<0.0001$; Figure $4 A)$. Of the 118 FANCD2-negative patients, only $4 \%$ survived to the census date, with a median survival time of $\sim 47$ months. In the borderline class, $64 \%$ of 65 patients were alive at the census date, in the intermediate FANCD2-positive group (+) 94\% of 52 patients survived, in the moderate class $(++) 84 \%$ of 31 patients survived, whereas in the strong FANCD2-positive staining class $(+++)$ all 5 patients survived to the census date; all with a median survival time of greater than 204 months (Figure $4 A)$. The differences between the negative $(-)$ and borderline $(+/-)$ staining class and between the borderline $(+/-)$ and intermediate $(+)$ staining class were highly significantly different $(P<0.0001)$, but those between the intermediate $(+)$ and moderate $(++)$, and between the moderate $(++)$ and strong $(+++)$ staining class were not significant $(P=0.15$ and $P=0.43$, respectively, Figure 4A). The RR for survival using Cox's univariate analysis varied from $4.97(95 \% \mathrm{Cl}, 3.29-7.52)$, through 7.25 (95\% Cl, 2.20-23.7), to 2.97 (95\% Cl, 0.71-12.4) for negative versus borderline, borderline versus intermediate, and intermediate versus moderate, staining class, respectively. Since there were no deaths due to breast cancer in the strong FANCD2-positive staining group (Figure $4 \mathrm{~A}$ ), the RR between the moderate and strong staining classes was not determinable.

Patients were separated into two categorical groups using a cut-off of $1 \%$ carcinoma cells stained for cytoplasmic FANCD2 (Figure 4B), since this cut-off gave the most significant difference in survival times above (Figure $4 A)$. Of the 118 patients who were identified as being FANCD2-negative, $4 \%$ were alive at the census date, compared with $77 \%$ of the patients classed as FANCD2positive. The median survival time of patients who were classified as FANCD2-negative was $\sim 47$ months, in comparison with $>228$ months for those patients classed as FANCD2-positive. Over a period of 20 years, patients with FANCD2-negative carcinomas had a highly significantly poorer survival rate than those with FANCD2-positive carcinomas (Wilcoxon test, $P<0.0001$ ); significant differences were achieved after only 6 months of follow-up ( $\chi^{2}=9.90 ; 1$ d.f.; $\left.P=0.002\right)$. Patients with FANCD2-negative tumors had a RR of $8.46(95 \% \mathrm{Cl}$, $5.77-12.41$ ) of dying (Figure 4B) or an RR of surviving of $0.12(95 \% \mathrm{Cl}, 0.08-0.17)$. Similarly at the $5 \%$ cut-off, the two curves were still significantly different $(P<0.0001)$, but with a reduced level of significance $\left(\chi^{2}=65.02,1\right.$ d.f.) compared with that at the $1 \%$ cut-off of stained carcinoma cells $\left(\chi^{2}=117.14,1\right.$ d.f. $)$.

\section{Association of FANCD2 and Other Tumor Variables with Patient Survival}

In addition to staining for cytoplasmic FANCD2, the other tumor variables that showed a significant association with survival time for this group of patients were: tumor size (Wilcoxon test, $P=0.003 ; \mathrm{RR}=1.50)$, histological grade $(P=0.002 ; \mathrm{RR}=1.59)$, nodal status $(P<0.0001 ; \mathrm{RR}=$ 2.00), staining for OPN $(P<0.0001 ; \mathrm{RR}=21.5)$, S100A4 $(P<0.0001 ; \mathrm{RR}=8.75), \mathrm{c}$-erbB-2 $(P=0.002 ; \mathrm{RR}=$ 1.69), estrogen receptor $\alpha(P=0.028 ; \mathrm{RR}=0.74)$, p53 $(P=0.032 ; \mathrm{RR}=1.31), \mathrm{S} 100 \mathrm{P}(P<0.0001 ; \mathrm{RR}=7.34)$, and AGR2 $(P<0.0001 ; \mathrm{RR}=30.5)$; staining for $\mathrm{C}-$ 
Table 3. Association of Immunocytochemical Staining for Cytoplasmic FANCD2 with Other Tumor Variables

\begin{tabular}{|c|c|c|c|c|}
\hline \multirow[b]{2}{*}{ Tumor variable* } & \multirow{2}{*}{$\begin{array}{c}\text { FANCD2 negative } \\
\text { no }(\%)\end{array}$} & \multirow{2}{*}{$\begin{array}{c}\text { FANCD2 positive } \\
\text { no }{ }^{+}(\%)\end{array}$} & \multicolumn{2}{|c|}{ Statistical significance ${ }^{\ddagger}$} \\
\hline & & & Uncorrected & Corrected \\
\hline $\begin{array}{l}\mathrm{LN}- \\
\mathrm{LN}+\end{array}$ & $\begin{array}{l}36(42.9) \\
48(57.1)\end{array}$ & $\left.\begin{array}{l}80(56.3) \\
62(43.7)\end{array}\right\}$ & 0.055 & 0.57 \\
\hline $\begin{array}{l}\text { Tumor }<5 \mathrm{~cm} \\
\text { Tumor }>5 \mathrm{~cm}\end{array}$ & $\begin{array}{l}78(69) \\
35(31)\end{array}$ & $\left.\begin{array}{r}147(79) \\
39(21)\end{array}\right\}$ & 0.055 & 0.57 \\
\hline $\begin{array}{l}\text { GradeI+II } \\
\text { Grade III }\end{array}$ & $\begin{array}{l}65(62.5) \\
39(37.5)\end{array}$ & $\left.\begin{array}{r}140(80.9) \\
33(19.1)\end{array}\right\}$ & 0.0011 & 0.016 \\
\hline $\begin{array}{l}\text { OPN- } \\
\text { OPN+ }\end{array}$ & $\begin{array}{c}11(9.6) \\
103(90.4)\end{array}$ & $\left.\begin{array}{r}86(46) \\
101(54)\end{array}\right\}$ & $<0.0001$ & $<0.0001$ \\
\hline $\begin{array}{l}\text { c-erbB-2 } \\
\text { c-erbB-2+ }\end{array}$ & $\begin{array}{l}83(72.2) \\
32(27.8)\end{array}$ & $\left.\begin{array}{r}155(80.3) \\
38(19.7)\end{array}\right\}$ & 0.122 & 0.86 \\
\hline $\begin{array}{l}\text { c-erbB-3- } \\
\text { c-erbB-3+ }\end{array}$ & $\begin{array}{l}51(46.4) \\
59(53.6)\end{array}$ & $\left.\begin{array}{r}69(36.1) \\
122(63.9)\end{array}\right\}$ & 0.088 & 0.75 \\
\hline $\begin{array}{l}\text { S100A4- } \\
\text { S100A4+ }\end{array}$ & $\begin{array}{l}42(35.6) \\
76(64.4)\end{array}$ & $\left.\begin{array}{r}145(74.7) \\
49(25.3)\end{array}\right\}$ & $<0.0001$ & $<0.0001$ \\
\hline $\begin{array}{l}\text { S100P- } \\
\text { S100P+ }\end{array}$ & $\begin{array}{l}33(32) \\
70(68)\end{array}$ & $\left.\begin{array}{l}94(55.6) \\
75(44.4)\end{array}\right\}$ & 0.0002 & 0.0025 \\
\hline $\begin{array}{l}\mathrm{ER} \alpha- \\
\mathrm{ER} \alpha+\end{array}$ & $\begin{array}{l}59(52.2) \\
54(47.8)\end{array}$ & $\left.\begin{array}{r}83(43) \\
110(57)\end{array}\right\}$ & 0.124 & 0.86 \\
\hline $\begin{array}{l}\mathrm{PgR}- \\
\mathrm{PgR}+\end{array}$ & $\begin{array}{l}76(67.3) \\
37(32.7)\end{array}$ & $\left.\begin{array}{r}105(56.8) \\
80(43.2)\end{array}\right\}$ & 0.087 & 0.74 \\
\hline $\begin{array}{l}\text { p53- } \\
\text { p53+ }\end{array}$ & $\begin{array}{l}69(59) \\
48(41)\end{array}$ & $\left.\begin{array}{r}120(61.5) \\
75(38.5)\end{array}\right\}$ & 0.720 & 1.00 \\
\hline $\begin{array}{l}\text { Cathepsin D- } \\
\text { Cathepsin D+ }\end{array}$ & $\begin{array}{l}20(21.5) \\
73(78.5)\end{array}$ & $\left.\begin{array}{r}25(16.4) \\
127(83.6)\end{array}\right\}$ & 0.39 & 1.00 \\
\hline $\begin{array}{l}\mathrm{pS} 2- \\
\mathrm{pS} 2+\end{array}$ & $\begin{array}{l}70(61.4) \\
44(38.6)\end{array}$ & $\left.\begin{array}{r}113(58.2) \\
81(41.8)\end{array}\right\}$ & 0.088 & 0.75 \\
\hline $\begin{array}{l}\text { AGR2- } \\
\text { AGR2+ }\end{array}$ & $\begin{array}{l}12(11.2) \\
95(88.8)\end{array}$ & $\left.\begin{array}{r}89(46.4) \\
103(53.6)\end{array}\right\}$ & $<0.0001$ & $<0.0001$ \\
\hline $\begin{array}{l}\text { Ki67- } \\
\text { Ki67+ }\end{array}$ & $\begin{array}{l}34(47.9) \\
37(52.1)\end{array}$ & $\left.\begin{array}{l}45(36.3) \\
79(63.7)\end{array}\right\}$ & 0.13 & 0.88 \\
\hline
\end{tabular}

*LN, lymph node with tumor (+) or without tumor deposits (-); tumor size $>5 \mathrm{~cm}(+),<5 \mathrm{~cm}$ in diameter (-); grade, histological grade III versus histological grades I and II; the presence $(+)$ or absence $(-)$ of immunocytochemical staining for osteopontin (OPN), C-erbB-2, C-erbB-3, S100A4 S100P, progesterone receptor (PgR), p53, pS2 using a 5\% cut-off and the presence (+) or absence (-) of staining for cathepsin D, AGR2 and nuclear Ki67 using a 1\% cut-off (Materials and Methods).

†Number of patients with carcinomas either classified as staining (positive) or not staining (negative) for cytoplasmic FANCD2 using a $1 \%$ cut-off between the positive and the negative groups. Brackets show the percentage of patients.

${ }^{\ddagger}$ Probability, $P$ from Fisher's Exact test (two sided values) either uncorrected or corrected using the Holm-Bonferroni adjustment $1-(1-P)^{n}$ where $n=15$ (Materials and Methods).

erbB-3, pS2, cathepsin D and nuclear Ki-67 $(P=0.33$; $\mathrm{RR}=1.23$ ) were not significantly associated (Supplemental Table S3, at http://ajp.amjpathol.org). All tumor variables except S100A4 had smaller values of the Wilcoxon statistic $\chi^{2}$ and hence higher $P$ values than FANCD2. Most of the tumor variables have RRs $>1$, but estrogen receptor $\alpha$, progesterone receptor, and particularly FANCD2 had RR $<1$ (Supplemental Table S3, at http://ajp.amjpathol.org). To determine whether the variables that were significant in the univariate analyses were independent of one another, they were all subjected to Cox's multivariate regression analysis. The first variable to emerge as the most significant independent variable was cytoplasmic staining for FANCD2, followed by staining for S100P, AGR2, c-erbB-2, S100A4, p53, and OPN (Table 4); the pathological variables were eliminated from the final equation in the stepwise analysis (Supplemental Table S4, at http://ajp.amjpathol.org).

\section{Discussion}

The purpose of this study has been to establish the intracellular site and level of expression of FANCD2 as an indicator of the activity of the FA/BRCA tumor suppressor pathway in human breast cancer. The antibodies used here do not distinguish between non-ubiquitylated and monoubiquitylated FANCD2 (Figure 2). ${ }^{11,20,43}$ We found FANCD2 in the nucleus of the majority of cells from benign breast lesions, consistent with its reported occurrence in normal breast ductal epithelium, ${ }^{45}$ and that there is a dramatic reduction in the level of immunoreactive nuclear FANCD2 in invasive ductal carcinoma, also in agreement with a previous report. ${ }^{24}$ However, the level of $19 \%$ of breast carcinomas containing no detectable FANCD2 in that report is almost half of that found in our group of breast cancers. This difference may be due to differences in patient groups (mean age 65 vs. 60 years), aggressiveness of the carci- 
nomas (39 vs. $49 \%$ involved lymph nodes), methods of detection (prior microwaving versus no microwaving) and/or scoring (zero staining vs $<1 \%$ carcinoma cells stained) between studies. Our novel finding over a previous report ${ }^{24}$ is that virtually all of the staining in the carcinomas occurs in the cytoplasm and not in the nucleus.

The almost complete loss of nuclear staining and the novel heterogeneous cytoplasmic staining pattern of the carcinomatous tissue for FANCD2 is not due to lack of accessibility of the antigen for its specific antibody. The same results have been achieved in experiments (a) using carcinomas preserved in Methacarn ${ }^{36}$ instead of formalin, (b) increasing antibody concentration fivefold, (c) incubating for $>3$ hours, (d) by attempting antigen retrieval by prior microwaving of sections ${ }^{24}$ and (e) in malignant tissue containing nuclear staining of incorporated benign lesions (Table 1). This dramatic fall in nuclear, and the retention of cytoplasmic, staining for FANCD2 has also been confirmed in malignant breast
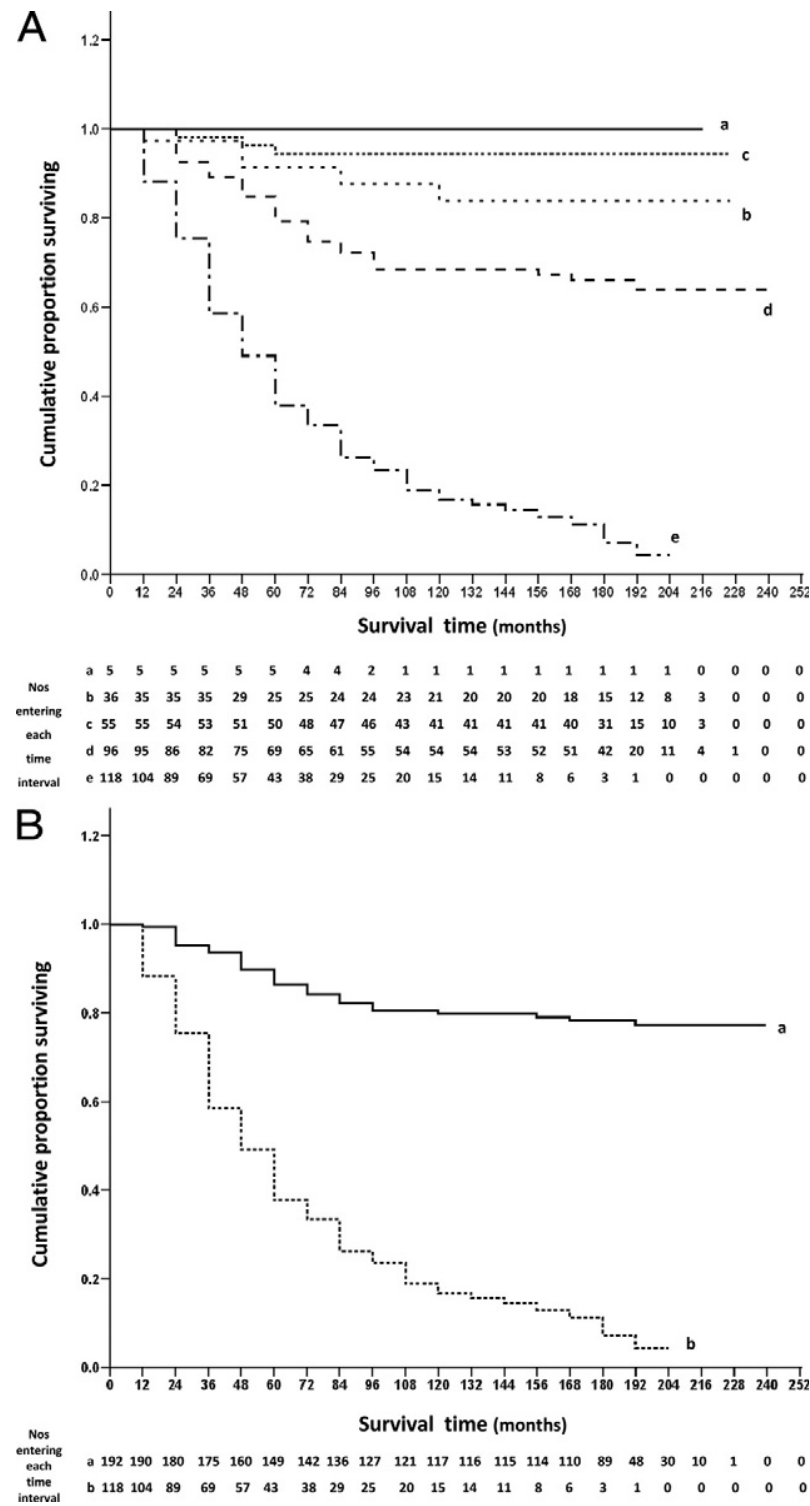

epithelial cell lines by immunocytochemical staining (Table 2), by direct immunofluorescence (Supplemental Figures S4, and S5, at http://ajp.amjpathol.org) and by Western blotting of separated nuclear and cytoplasmic extracts (Figure 2A). The immunocytochemical staining for FANCD2 is also specific for this molecule for the following reasons: (a) Prior incubation of immunizing peptide with the rabbit antibody abolishes completely its cytoplasmic staining of all carcinoma cells, as shown in Figure $1, G$ and $H$, as well as the predominantly nuclear staining of the benign lesions (Supplemental Figures S1 and S2, at $h$ ttp://ajp.amjpathol.org); (b) The same staining patterns are achieved in pilot studies with an independent anti-FANCD2 serum (Supplemental Figure S3, and Supplemental Table S2, at http://ajp.amjpathol.org); (c) Immunocytochemical staining was largely absent in cell lines from FA-D2 patients (PD733 and PD20) that express FANCD2 protein at undetectable levels by Western blotting $^{11,32}$ (Figure 2B). All such FA-D2 patients are hypomorphic, in which at least one of the mutant alleles encodes an unstable protein present at very low level. ${ }^{46}$ It is therefore not surprising that a very low level (1 to $2 \%$ ) of FANCD2 is detected above background by immunocytochemistry (Table 2) than by Western blots (Figure 2B), which are not normally capable of this level of detection. ${ }^{32}$ FANCD2 staining was clearly observed in the nucleus and cytoplasm of PD20-3-15 cells (Table 2) that express both FANCD2-L (monoubiquitylated) and FANCD2-S (non-monoubiquitylated) in the nucleus, ${ }^{11,20,32}$ but only FANCD2-S in the cytoplasm (Figure 2B).

There is a highly significant difference between the nuclear location of FANCD2 in benign and malignant breast lesions, with only one malignant tumor showing

Figure 4. Association of immunocytochemical staining of the primary carcinoma for cytoplasmic FANCD2 with overall survival of patients. A: The cumulative proportion of patients surviving as a fraction of the total at 12 monthly intervals after presentation for patients with carcinomas classified as follows: (a) +++ , strong staining (- ; 100\% $=5$ patients); (b) ++ moderate staining $(-----; 100 \%=36$ patients $) ;(\mathbf{c})+$, intermediate staining $(\ldots \ldots . . ; 100 \%=55$ patients $) ;(\mathbf{d})+/-$, borderline staining $(---) ; 100 \%=96$ patients) and (e) - , negative staining $(-\ldots, 100 \%=118$ patients) for FANCD2. There were 5 censored observations in a ( 4 dead of other causes (doc); cumulative proportion surviving $(\mathrm{cps})=100 \%$; median survival time (mst) $>204$ months); 31 in b ( 14 doc; $\mathrm{cps}=84 \%$; mst $>216$ months); 52 in c $(13$ doc; $\mathrm{cps}=94 \%$; mst $>216$ months); 65 in d (17 doc; $\mathrm{cps}=64 \%$; $\mathrm{mst}$ $>228$ months); and 15 in e (12 doc; $\mathrm{cps}=4 \%$; mst $=46.8$ months). The cumulative proportions surviving $\pm 95 \%$ CIs were (a) $1.00 \pm 0.0$, (b) $0.91 \pm$ 0.05 , (c) $0.94 \pm 0.03$, (d) $0.75 \pm 0.05$, and (e) $0.33 \pm 0.04$, after 5 years; (a) $1.00 \pm 0.0$, (b) $0.84 \pm 0.07$, (c) $0.94 \pm 0.03$, (d) $0.69 \pm 0.05$, and (e) $0.16 \pm$ 0.03 , after 10 years; (a) $1.00 \pm 0.0$, (b) $0.84 \pm 0.07$, (c) $0.94 \pm 0.03$, (d) $0.64 \pm$ 0.05 , and (e) $0.04 \pm 0.03$, after 15 years; and (a) $1.00 \pm 0.0$, (b) $0.84 \pm 0.07$, (c) $0.94 \pm 0.03,(\mathbf{d}) 0.64 \pm 0.05$, and (e) $0.04 \pm 0.03$, after 20 years. The five curves were significantly different (Wilcoxon statistic $\chi^{2}=125.83$, 4 d.f., $P<$ $0.0001)$, and significantly different in the successive pairwise combinations of $\mathbf{c}$ with $\mathbf{d}\left(\chi^{2}=13.85,1\right.$ d.f., $\left.P<0.0001\right)$ and $\mathbf{d}$ with $\mathbf{e}\left(\chi^{2}=53.29,1\right.$ d.f., $P<$ $0.0001)$ but not $\mathbf{b}$ with $\mathbf{c}\left(\chi^{2}=2.03,1\right.$ d.f., $\left.P=0.155\right)$ nor $\mathbf{a}$ with $\mathbf{b}\left(\chi^{2}=0.63\right.$ 1 d.f., $P=0.43)$. The malignant grade of the 5 strong staining carcinomas $(+++)(\mathbf{a})$ was confirmed as grade I (2 patients), II ( 2 patients), and III (1 patient). B: The cumulative proportion of patients surviving as a fraction of the total at 12 month intervals after presentation with carcinomas classified as (a) positive staining using a $1 \%$ cut off $(-; 100 \%=192$ patients) and (b) - , negative staining (---- ; 100\% $=118$ patients) for FANCD2. There were 153 censored observations in $\mathbf{a}$ ( $48 \mathrm{doc}$; $\mathrm{cps}=77 \%$; mst $>228$ months) and 15 in b ( 12 doc; $\mathrm{cps}=4 \% ; \mathrm{mst}=46.8$ months). The cumulative proportions surviving $\pm 95 \%$ CIs were (a) $0.84 \pm 0.03$, (b) $0.33 \pm 0.04$, after 5 years; (a) $0.80 \pm 0.03$, (b) $0.16 \pm 0.03$, after 10 years; (a) $0.77 \pm 0.03$, (b) $0.04 \pm 0.03$ after 15 years; and (a) $0.77 \pm 0.03$, (b) $0.04 \pm 0.03$, after 20 years. The two lines were significantly different (Wilcoxon statistic $\chi^{2}=117.14$, 1 d.f., $P<$ $0.0001)$. 
Table 4. Summary of the Cox's Proportional Hazards Model for Cancer-Related Deaths

\begin{tabular}{ccccccc}
\hline Tumor variable* & Coefficient $\beta^{\dagger}$ & $\mathrm{SE}^{\ddagger}$ & $\chi^{2 \S}$ & $P^{\mathbb{}}$ & $\mathrm{RR}^{\|}$ & $95 \% \mathrm{Cl}$ \\
\hline FANCD2 & -0.875 & 0.26 & 11.11 & 0.001 & 0.42 & $0.25-0.70$ \\
AGR2 & 2.03 & 0.62 & 10.72 & 0.001 & 7.64 & $2.26-25.8$ \\
S100P & 0.985 & 0.32 & 9.33 & 0.002 & 2.68 & $1.42-5.04$ \\
OPN & 1.16 & 0.55 & 4.47 & 0.034 & 3.20 & $1.09-9.43$ \\
S100A4 & 0.659 & 0.28 & 5.68 & 0.017 & 1.93 & $1.12-3.33$ \\
p53 & 0.605 & 0.26 & 5.40 & 0.020 & 1.83 & $1.10-3.05$ \\
C-erbB-2 & 0.733 & 0.28 & 6.72 & 0.010 & 2.08 & $1.20-3.62$ \\
\hline
\end{tabular}

*Tumor variable that showed a statistically significant association with patient survival times in the univariate analysis for 159 patient cases with full data sets. Only comparison between patients with involved lymph nodes, all tumor sizes ( $\left.T_{1}-T_{4}\right)$, all histological grades (I-III), staining for FANCD2, AGR2, S100P, S100A4, OPN, ER $\alpha$, p53, and c-erbB-2 were made. Analysis is shown in full in Supplementary Table S4 (see http://ajp.amjpathol.org).

†Value of $\beta$ parameter $\left(=\log _{\mathrm{e}} \mathrm{RR}\right)$ in the Cox's multiple regression analysis (Materials and Methods).

‡SE of $\beta$.

¿ox's statistic $\chi^{2}$

TProbability from Cox's statistic $\chi^{2}$, 1 d.f. in each case. Overall $\chi^{2}=130.11,7$ d.f., $P<0.001$; residual $\chi^{2}=10.91,4$ d.f., $P=0.028$.

"RR for survival and $95 \% \mathrm{Cl}$ from multivariate analysis.

borderline nuclear staining, although $>62 \%$ of both types of lesions show cytoplasmic staining for FANCD2. This difference has been confirmed in malignant breast epithelial cell lines using immunocytochemical staining of paraffin-embedded cells (Table 2), immunofluorescence with two different antibodies (Supplemental Figures S4 and S5, at $h$ ttp://ajp.amjpathol.org) and Western blotting of separated nuclear and cytoplasmic extracts (Figure 2A). Since benign lesions within carcinomas still retain their nuclear staining for FANCD2, this change is specific to the malignant state, and is not a field effect caused by extracellular processes. Since nuclear FANCD2, and specifically monoubiquitylated FANCD2 located in chromatin, ${ }^{14,15}$ is generally considered to be its active form in DNA repair processes, the predominant cytoplasmic location of the smaller $155 \mathrm{kDa}$, non-monoubiquitylated FANCD2 in malignant cells (Figure 2A) suggests that FANCD2-mediated DNA repair would be severely compromised. Interestingly, a recent study also reported the cytoplasmic retention of BRCA1 and RAD51 in a high frequency of sporadic breast cancers, ${ }^{47}$ proteins known to associate in the nucleus with FANCD2. The reasons for failure of FANCD2 to locate to the nucleus in these cells is unclear, although it may reflect a reduction in or damage to any of the FA core complex proteins, ${ }^{8}$ rare mutations in FANCD2 ${ }^{48}$ or changes in activity of kinases, ATM, ATR or CHK1, reported to phosphorylate FANCD2 or other FA proteins. ${ }^{20,33,49-51}$ Regardless of the reasons for the lack of nuclear FANCD2, it will result in the loss of colocalization with RAD51, BRCA1, and BRCA2 in nuclear foci, ${ }^{12,13,19}$ disrupting the processing of DNA damage. We suggest that, unlike the benign lesions, the reduction in nuclear FANCD2 allows most malignant tumors to arise irrespective of their prognosis due to greater chromosomal breakage, and genomic instability. ${ }^{8,52}$ Certainly, we have demonstrated that the malignant cell line MDA-MB-157, which lacks detectable FANCD2 by Western blotting (Figures $2 \mathrm{~A}$ and $3 \mathrm{~A}$ ), exhibits cellular hypersensitivity and a high degree of chromatid breaks and exchanges in response to MMC; phenotypes that are reversed by introduction of an expression vector for FANCD2 (Figures $3 \mathrm{~B}$ and $3 \mathrm{C}$ ).

When the patients are grouped into classes according to the \% cytoplasmic staining for FANCD2, the class proportion of stained carcinoma cells is highly significantly correlated with the time of survival of the patients using Wilcoxon statistics (Figure 4A), and confirmed by log-rank sums (Mantel-Cox $\chi^{2}=171.4,4$ d.f., $P<$ 0.0001). On subsequent division into two categorical staining groups, the overall survival for patients with positively stained carcinomas is highly significantly better than for those patients classified as negative for FANCD2, using either Wilcoxon statistics (Figure 4B) or log-rank sums (Mantel-Cox $\chi^{2}=164.5,1$ d.f., $P<$ 0.0001). Our results demonstrate that the relationship is not dependent on the statistical test or level of cut-off used, and is more significant than almost all other tumor variables tested (Supplemental Table S3, at http://ajp. amjpathol.org). Thus unlike a previous report that showed that high FANCD2 expression appeared to be prognostically unfavorable for overall survival (log-rank test, $P=$ $0.03),{ }^{24}$ our novel result is that it is the reduction in expression of cytoplasmic FANCD2 that is highly significantly correlated with unfavorable survival in our group of breast cancer patients. The RR of death of patients with FANCD2-negative tumors compares favorably with that of the metastasis-inducing proteins AGR2, OPN, S100A4, and $\mathrm{S} 100 \mathrm{P}$, and is much greater than for the other tumor variables (Supplemental Table S3, at $h$ ttp://ajp.amjpathol. org). However, unlike the other four metastasis-inducing proteins, ${ }^{1-4}$ the class level of cytoplasmic staining for FANCD2 fails to show a significant difference in patient death above a critical threshold of 25 to $50 \%$ of carcinoma cells stained for FANCD2. This association of loss of cytoplasmic staining for FANCD2 with aggressiveness of the primary breast cancer is largely confirmed by results with the breast carcinoma cell lines, where cytoplasmic FANCD2 staining is associated with cells that are relatively weakly invasive in vitro (MCF-7, T47D), but not with those cells that are highly invasive in vitro (MDA-MB157, MDA-MB-231). It is possible that FANCD2-negative tumors may have an increased sensitivity to chemotherapy and, to a lesser extent, radiation. ${ }^{53}$ The former possibility is supported by the enhanced sensitivity to MMC obtained here with the highly invasive but FANCD2-negative cell lines. However, if the FANCD2-negative tumors have already metastasized at the time of surgical removal of the primary, whereas FANCD2-positive tumors have 
not, then the FANCD2-negative tumors will carry a poorer prognosis independent of any subsequent treatment in our group of patients. Similar arguments apply to any potential decrease in the repopulation ability of FANCD2negative breast cancer cells. ${ }^{53}$

It is not immediately clear why loss of cytoplasmic FANCD2 is associated with poor prognosis when FANCD2, and specifically monoubiquitylated FANCD2, is considered to function predominantly in chromatin. However, we note that BRCA1, another protein with ostensibly nuclear functions, shuttles between the nucleus and cytoplasm and has been proposed to have a pro-apoptotic function in the cytoplasm ${ }^{54}$ It is possible that the cytoplasmic location of FANCD2 is merely a defect in nuclear uptake/retention so that reduction in cytoplasmic FANCD2 may lead to further reductions in the remaining small, relatively undetectable levels of FANCD2 in the nucleus of the malignant cells, so impairing the FA/BRCA pathway completely. However, the more likely explanation is that non-monoubiquitylated FANCD2 has an alternative protective role in the cytoplasm of cells, such that when it falls below a critical threshold, cancer cells can progress to an aggressive form. In support of this hypothesis, a chromatographically separable form of the FA core complex ${ }^{55}$ and other complexes containing FA proteins have been reported in the cytoplasm. ${ }^{56}$ For example, FANCC, binds with signaling and chaperone proteins including GRP94, Hsp70, and STAT1 in both pro-apoptotic and survival signaling pathways ${ }^{16}$ and with FANCD2 in multimeric high-molecular-weight complexes in cytokine-stimulated cells, ${ }^{16}$ while oxidative stress induces FANCD2 interaction with STAT5 and promotes STAT5-dependent survival signals. ${ }^{57}$ Depletion of cytoplasmic FANCD2 might possibly disrupt these pathways. Furthermore, FA cells are reported to be defective in oxygen metabolism, ${ }^{52,58}$ and metastatic cancers are associated with cellular oxidative stress. ${ }^{59}$ Loss of FANCD2 also leads to oxidative stress ${ }^{60}$ and the anti-oxidant tempol has been shown to protect against epithelial tumor onset in fancd2-deficient mice. ${ }^{61}$

When the tumor variables that have shown a significant association with patient survival in this group of breast cancer patients ${ }^{2-4,38}$ are tested for association with immunocytochemical staining for FANCD2 in the primary carcinomas, staining for the four metastasis-inducing proteins AGR2, OPN, S100A4, and S100P are the most significantly associated with negative staining for cytoplasmic FANCD2 $(P \leq 0.002)$, followed by high histological grade $(P=0.015$ ), at both the $1 \%$ and $5 \%$ (not shown) cut-off levels. These results may suggest that the underlying mechanism responsible for the enhanced expression of these four metastasis-inducing proteins is related to a decrease in overall FANCD2. However, since there is not a completely coordinated response (Table 3), the relationship is more likely to be indirect rather than direct. Although \% nuclear staining for Ki-67 has been significantly positively correlated by linear regression with that for FANCD2, ${ }^{24}$ this is not the case with our patients, when separated into two categorical groups using either a 1\% (Table 3) or 5\% (Fisher's Exact test, $P=$ 0.73 , corrected $P=1.0$ ) cut-off between the positive and negative Ki-67-staining tumors. This difference may be due to the fact that nuclear staining for Ki-67 in our nonadjuvantly treated patients (Materials and Methods) lies at the lower, nonsignificant end of association with patient death (RRs at $1 \%, 5 \%, 25 \%$ cut-offs $=1.23,1.26$, 1.07 , respectively; $P \geq 0.32$ ) when results with different patient groups are compared in a meta-analysis of over 1200 patients $(\mathrm{RR}=1.79 ; 95 \% \mathrm{Cl}, 1.22-2.63) .{ }^{62}$ Alternatively this difference may have arisen because the completely negative FANCD2 tumors that were all positive to varying percentages for $\mathrm{Ki}-67$ in the former analysis ${ }^{24}$ have not been excluded in our current analysis using just two categorical groups. In Cox's proportional hazards model, negative staining for cytoplasmic FANCD2 is the most significant independent prognostic indicator, followed by staining for the four metastasis-inducing proteins; c-erbB-2 and p53 (Table 4). Standard pathological variables are confounded by combinations of more powerful independent molecular variables (Supplemental Table S2, at $h$ ttp://ajp.amjpathol.org). The combination of reduced levels of cytoplasmic FANCD2 and overproduction of four proteins that can induce metastasis in a rat mammary model ${ }^{4,27,63,64}$ has identified a subgroup of breast cancer patients with a poor outcome. It is possible that a lowering of the overall levels of FANCD2 reflects a further deficiency in the FA/BRCA tumor suppressor pathway that allows selection for overexpression of those metastasis-inducing genes most likely to progress the cancer. Alternatively, FANCD2 may have an, as yet, uncharacterized role in the cytoplasm, loss of which could promote the progression of breast cancer by the same metastasis-inducing genes. Whatever the case, loss of cytoplasmic FANCD2 may be clinically useful not only as a test for poor prognosis, but also for identifying patients for therapy with agents targeted to DNA repair defective tumors, analogous to the proposed use of PARP1 inhibitors in the treatment of hereditary BRCA $1 / 2$ breast cancer. ${ }^{65}$

\section{Acknowledgments}

We thank Mr. Christopher Holcombe and The Breast Unit, Royal Liverpool University Hospital for clinical assistance, Dr. Evelyn Williams and the staff of the North West Cancer Intelligence Service (Liverpool Office) for providing patient outcome data, Joe Carroll and Nicola Hedges for excellent technical assistance, and Dr. Marcus Grompe (Oregon Health Sciences University) for providing the PD733 cell line.

\section{References}

1. Barraclough DL, Platt-Higgins A, de Silva Rudland S, Barraclough R, Winstanley JHR, West CR, Rudland PS: The metastasis associated Anterior Gradient 2 protein is correlated with poor survival of breast cancer patients. Am J Pathol 2009, 175:1848-1857

2. Rudland PS, Platt-Higgins A, Renshaw C, West CR, Winstanley JHR, Robertson L, Barraclough R: Prognostic significance of the metastasis-inducing protein S100A4 (p9Ka) in human breast cancer. Cancer Res 2000, 60:1595-1603

3. Rudland PS, Platt-Higgins A, El-Tanani M, Rudland SDS, Barraclough 
R, Winstanley JHR, Howitt R, West CR: Prognostic significance of the metastasis-associated protein osteopontin in human breast cancer. Cancer Res 2002, 62:3417-3427

4. Wang GZ, Platt-Higgins A, Carroll J, Rudland SD, Winstanley J, Barraclough R, Rudland PS: Induction of metastasis by S100P in a rat mammary model and its association with poor survival of breast cancer patients. Cancer Res 2006, 66:1199-1207

5. Boulton SJ: Cellular functions of the BRCA tumour-suppressor proteins. Biochem Soc Transact 2006, 34:633-645

6. Nagaraju G, Scully R: Minding the gap: the underground functions of BRCA1 and BRCA2 at stalled replication forks. DNA Repair 2007 6:1018-1031

7. Thompson LH, Hinz JM: Cellular and molecular consequences of defective Fanconi anemia proteins in replication-coupled DNA repair: mechanistic insights. Mut Res/Fund Mol Mech Mutagenesis 2009, 668:54-72

8. Wang WD: Emergence of a DNA-damage response network consisting of Fanconi anaemia and BRCA proteins. Nat Rev Genet 2007, 8:735-748

9. Howlett NG, Taniguchi T, Olson S, Cox B, Waisfisz Q, de Die-Smulders C, Persky N, Grompe M, Joenje H, Pals G, Ikeda H, Fox EA, D'Andrea AD: Biallelic inactivation of BRCA2 in Fanconi anemia. Science 2002 297:606-609

10. Alter BP: Cancer in Fanconi anemia, 1927-2001. Cancer 2003 97:425-440

11. Garcia-Higuera I, Taniguchi T, Ganesan S, Meyn MS, Timmers C, Hejna J, Grompe M, D'Andrea AD: Interaction of the Fanconi anemia proteins and BRCA1 in a common pathway. Mol Cell 2001, 7:249-262

12. Taniguchi T, Garcia-Higuera I, Andreassen PR, Gregory RC, Grompe M, D'Andrea AD: S-phase-specific interaction of the Fanconi anemia protein. FANCD2, with BRCA1 and RAD51. Blood 2002, 100:2414-2420

13. Wang $X Z$, Andreassen PR, D'Andrea AD: Functional interaction of monoubiquitinated FANCD2 and BRCA2/FANCD1 in chromatin. Mol Cell Biol 2004, 24:5850-5862

14. de Oca RM, Andreassen PR, Margossian SP, Gregory RC, Taniguchi T, Wang XZ, Houghtaling S, Grompe M, D'Andrea AD: Regulated interaction of the Fanconi anemia protein. FANCD2, with chromatin. Blood 2005, 105:1003-1009

15. Alpi A, Langevin F, Mosedale G, Machida YJ, Dutta A, Patel KJ UBE2T, the Fanconi anemia core complex, and FANCD2 are recruited independently to chromatin: a basis for the regulation of FANCD2 monoubiquitination. Mol Cell Biol 2007, 27:8421-8430

16. Bagby GC, Alter BP: Fanconi anemia. Sem Hematol 2006, 43 : $147-156$

17. Patel KJ: Fanconi anemia and breast cancer susceptibility. Nat Genet 2007, 39:142-143

18. Walsh T, King MC: Ten genes for inherited breast cancer. Cancer Cell 2007, 11:103-105

19. Hussain S, Wilson JB, Medhurst AL, Hejna J, Witt E, Ananth S, Davies A, Masson JY, Moses R, West SC, de Winter JP, Ashworth A, Jones $\mathrm{NJ}$, Mathew CG: Direct interaction of FANCD2 with BRCA2 in DNA damage response pathways. Hum Mol Genet 2004, 13:1241-1248

20. Wilson JB, Yamamoto K, Marriott AS, Hussain S, Sung P, Hoatlin ME, Mathew CG, Takata M, Thompson LH, Kupfer GM, Jones NJ: FANCG promotes formation of a newly identified protein complex containing BRCA2, FANCD2 and XRCC3. Oncogene 2008, 27:3641-3652

21. Houghtaling S, Timmers C, Noll M, Finegold MJ, Jones SN, Meyn MS, Grompe M: Epithelial cancer in Fanconi anemia complementation group D2 (FancD2) knockout mice. Genes Dev 2003, 17:2021-2035

22. Pejovic T, Yates JE, Liu HY, Hays LE, Akkari Y, Torimaru Y, Keeble W, Rathbun RK, Rodgers WH, Bale AE, Ameziane N, Zwaan CM, Errami A, Thuillier P, Cappuccini F, Olson SB, Cain JM, Bagby GC: Cytogenetic instability in ovarian epithelial cells from women at risk of ovarian cancer. Cancer Res 2006, 66:9017-9025

23. Mathew CG: Fanconi anaemia genes and susceptibility to cancer. Oncogene 2006, 25:5875-5884

24. van der Groep P, Hoelzel M, Buerger $\mathrm{H}$, Joenje $\mathrm{H}$, de Winter JP, van Diest PJ: Loss of expression of FANCD2 protein in sporadic and hereditary breast cancer. Breast Cancer Res Treatment 2008, 107:41-47

25. Anandappa SY, Winstanley JHR, Leinster S, Green B, Rudland PS, Barraclough R: Comparative expression of fibroblast growth factor messenger RNAs in benign and malignant breast disease. $\mathrm{Br} J$ Cancer 1994, 69:772-776
26. Winstanley JHR, Leinster SJ, Cooke TG, Westley BR, Platt-Higgins AM, Rudland PS: Prognostic significance of cathepsin-D in patients with breast cancer. Br J Cancer 1993, 67:767-772

27. Liu D, Rudland PS, Sibson DR, Platt-Higgins A, Barraclough R: Human homologue of cement gland protein, a novel metastasis inducer associated with breast carcinomas. Cancer Res 2005, 65:3796-3805

28. Rudland PS, Ollerhead G, Barraclough R: Isolation of Simian virus 40 transformed human mammary epithelial stem cell lines that can differentiate to myoepithelial-like cells in culture and in vivo. Dev Biol 1989, 136:167-180

29. Neve RM, Chin K, Fridlyand J, Yeh J, Baehner FL, Fevr T, Clark L, Bayani N, Coppe JP, Tong F, Speed T, Spellman PT, DeVries S, Lapuk A, Wang NJ, Kuo WL, Stilwell JL, Pinkel D, Albertson DG, Waldman FM, McCormick F, Dickson RB, Johnson MD, Lippman M, Ethier S, Gazdar A, Gray JW: A collection of breast cancer cell lines for the study of functionally distinct cancer subtypes. Cancer Cell 2006, 10:515-527

30. Zhi G, Wilson JB, Chen X, Krause DS, Xiao Y, Jones NJ, Kupfer GM: Fanconi Anemia complementation group FANCD2 protein serine 331 phosphorylation is important for Fanconi Anemia pathway function and BRCA2 interaction. Cancer Res 2009, 69:8775-8783

31. Mi J, Qiao F, Wilson JB, High AA, Schroeder MJ, Stukenberg PT, Moss A, Shabanowitz J, Hunt DF, Jones NJ, Kupfer GM: FANCG is phosphorylated at serines 383 and 387 during mitosis. Mol Cell Biol 2004, 24:8576-8585

32. Timmers C, Taniguchi T, Hejna J, Reifsteck C, Lucas L, Bruun D, Thayer M, Cox B, Olson S, D'Andrea AD, Moses R, Grompe M: Positional cloning of a novel Fanconi anemia gene, FANCD2. Molecular Cell 2001, 7:241-248

33. Collins NB, Wilson JB, Bush T, Thomashevski A, Roberts KJ, Jones NJ, Kupfer GM: ATR-dependent phosphorylation of FANCA on serine 1449 after DNA damage is important for FA pathway function. Blood 2009, 113:2181-2190

34. Jones NJ, Ellard S, Waters R, Parry EM: Cellular and chromosomal hypersensitivity to DNA cross-linking agents and topoisomerase inhibitors in the radiosensitive Chinese hamster irs mutants-phenotypic similarities to ataxia-telangiectasia and Fanconi's anemia cells. Carcinogenesis 1993, 14:2487-2494

35. Scott D, Dean BJ, Danford ND, Kirkland DJ: Metaphase chromosome aberration assays in vitro. Basic Mutagenicity Tests: UKEMS recommended procedures. Edited by DJ Kirkland. Cambridge, Cambridge University Press, 1990, pp 62-86

36. Gusterson BA, Warburton MJ, Mitchell D, Ellison M, Neville AM, Rudland PS: Distribution of myoepithelial cells and basement membrane proteins in the normal breast and in benign and malignant breast diseases. Cancer Res 1982, 42:4763-4770

37. Sabattini E, Bisgaard K, Ascani S, Poggi S, Piccioli M, Ceccarelli C, Pieri F, Fraternali-Orcioni G, Pileri SA: The EnVision (TM)+ system: a new immunohistochemical method for diagnostics and research. Critical comparison with the APAAP, ChemMate (TM), CSA, LABC, and SABC techniques. J Clin Pathol 1998, 51:506-511

38. Platt-Higgins AM, Renshaw CA, West CR, Winstanley JHR, Rudland SD, Barraclough R, Rudland PS: Comparison of the metastasis-inducing protein S100A4 (p9Ka) with other prognostic markers in human breast cancer. Int J Cancer 2000, 89:198-208

39. Kilty IC, Barraclough R, Schmidt G, Rudland PS: Isolation of a potential neural stem cell line from the internal capsule of an adult transgenic rat brain. J Neurochem 1999, 73:1859-1870

40. Altman D: Practical statistics for medical research. London, Chapman and Hall, 1991, pp 371-375

41. Winstanley J, Cooke T, Murray GD, Platt-Higgins A, George WD, Holt S, Myskov M, Spedding A, Barraclough BR, Rudland PS: The long term prognostic significance of c-erbB-2 in primary breast cancer. Br J Cancer 1991, 63:447-450

42. Cox DR: Regression models and life-tables. J Royal Stat Soc Ser B-Stat Methodol 1972, 34:187-220

43. Wilson JB, Johnson MA, Stuckert AP, Trueman KL, May S, Bryant PE, Meyn RE, D'Andrea AD, Jones NJ: The Chinese hamster FANCG/ XRCC9 mutant NM3 fails to express the monoubiquitinated form of the FANCD2 protein, is hypersensitive to a range of DNA damaging agents and exhibits a normal level of spontaneous sister chromatid exchange. Carcinogenesis 2001, 22:1939-1946

44. Auerbach AD: Fanconi anemia and its diagnosis. Mut Res/Fund Mo Mech Mutagenesis 2009, 668:4-10 
45. Hoelzel M, van Diest PJ, Bier P, Wallisch M, Hoatlin ME, Joenje H, de Winter JP: FANCD2 protein is expressed in proliferating cells of human tissues that are cancer-prone in Fanconi anaemia. J Pathol 2003, 201:198-203

46. Patel KJ, Joenje H: Fanconi anemia and DNA replication repair. DNA Repair 2007, 6:885-890

47. Plo I, Laulier C, Gauthier L, Lebrun F, Calvo F, Lopez BS: AKT1 inhibits homologous recombination by inducing cytoplasmic retention of BRCA1 and RAD51. Cancer Res 2008, 68:9404-9412

48. Barroso E, Milne RL, Fernandez LP, Zamora P, Arias JI, Benitez J, Ribas G: FANCD2 associated with sporadic breast cancer risk. Carcinogenesis 2006, 27:1930-1937

49. Wang XZ, Kennedy RD, Ray K, Stuckert P, Ellenberger T, D'Andrea AD: Chk1-mediated phosphorylation of FANCE is required for the Fanconi anemia/BRCA pathway. Mol Cell Biol 2007, 27:3098-3108

50. Ho GPH, Margossian S, Taniguchi T, D'Andrea AD: Phosphorylation of FANCD2 on two novel sites is required for mitomycin $C$ resistance. Mol Cell Biol 2006, 26:7005-7015

51. Taniguchi T, Garcia-Higuera I, Xu B, Andreassen PR, Gregory RC Kim ST, Lane WS, Kastan MB, D'Andrea AD: Convergence of the Fanconi anemia and ataxia telangiectasia signaling pathways. Cell 2002, 109:459-472

52. Thompson LH, Hinz JM, Yamada NA, Jones NJ: How Fanconi anemia proteins promote the four Rs: replication, recombination, repair, and recovery. Environ Mol Mutagenesis 2005, 45:128-142

53. Lyakhovich A, Surralles J: FANCD2 depletion sensitizes cancer cells repopulation ability in vitro. Cancer Lett 2007, 256:186-195

54. Henderson BR: Regulation of BRCA1. BRCA2 and BARD1 intracellular trafficking. Bioessays 2005, 27:884-893

55. Thomashevski A, High AA, Drozd M, Shabanowitz J, Hunt DF, Grant PA, Kupfer GM: The Fanconi anemia core complex forms four complexes of different sizes in different subcellular compartments. J Biol Chem 2004, 279:26201-26209

56. Bagby GC: The less-traveled Fanconi road. Blood 2006, 107: 4196-4197
57. Bagby G, Keeble W, Koretsky T, Zodrow D, Jove R, Hays L, Carlson $\mathrm{H}$ : Oxidative stress induces binding of FANCD2 to STAT5 and facilitates STAT5-dependent survival signals. Blood 2004, 104:13A-14A

58. Pagano G, Degan P, d'Ischia M, Kelly FJ, Nobili B, Pallardo FV, Youssoufian $\mathrm{H}$, Zatterale $\mathrm{A}$ : Oxidative stress as a multiple effector in Fanconi anaemia clinical phenotype. Eur J Haematol 2005, 75:93-100

59. Nicolson GL, Conklin KA: Reversing mitochondrial dysfunction, fatigue and the adverse effects of chemotherapy of metastatic disease by molecular replacement therapy. Clin Exp Metastasis 2008, 25:161-169

60. Willers H, Kachnic LA, Luo CM, Li L, Purschke M, Borgmann K, Held KD, Powell SN: Biomarkers and mechanisms of FANCD2 function. J Biomedicine Biotechnol 2008, Article ID 821529:doi:10.1155/2008/821529

61. Zhang QS, Eaton L, Snyder ER, Houghtaling S, Mitchell JB, Finegold M, van Waes C, Grompe M: Tempol protects against oxidative damage and delays epithelial tumor onset in Fanconi anemia mice. Cancer Res 2008, 68:1601-1608

62. de Azambuja E, Cardoso F, de Castro G, Colozza M, Mano MS Durbecq V, Sotiriou C, Larsimont D, Piccart-Gebhart MJ, Paesmans $\mathrm{M}$ : Ki-67 as prognostic marker in early breast cancer: a meta-analysis of published studies involving 12155 patients. Br J Cancer 2007, 96:1504-1513

63. Davies BR, Davies MPA, Gibbs FEM, Barraclough R, Rudland PS: Induction of the metastatic phenotype by transfection of a benign rat mammary epithelial cell line with the gene for p9ka, a rat calcium binding protein, but not with the oncogene EJ-Ras-1. Oncogene 1993, 8:999-1008

64. Oates AJ, Barraclough R, Rudland PS: The identification of osteopontin as a metastasis-related gene product in a rodent mammary tumour model. Oncogene 1996, 13:97-104

65. Jackson SP: The DNA-damage response: new molecular insights and new approaches to cancer therapy. Biochem Soc Transact 2009 $37: 483-494$ 